\title{
Simulating operational alternatives for future cement production
}

\author{
Karin Gäbel $^{\mathrm{a}, \mathrm{b}, *}$, Anne-Marie Tillman ${ }^{\mathrm{a}}$ \\ ${ }^{a}$ Environmental Systems Analysis, Chalmers University of Technology, S-412 96 Gothenburg, Sweden \\ ${ }^{\mathrm{b}}$ Cementa AB, Research \& Development, P.O. Box 144, S-182 12 Danderyd, Sweden
}

Accepted 3 May 2005

Available online 06 July 2005

\begin{abstract}
To support decisions on product and process development options and strategic planning, information on the consequences of planned changes are needed. For this purpose a flexible model for cement manufacturing has been developed. The model predicts the environmental, product and economic performance in a life cycle perspective, simulating different operational alternatives. Interesting future operational alternatives, such as an increase in the use of industrial by-products and wastes as raw materials and fuels have been explored. The results, i.e. the consequences from a life cycle perspective of potential development options, are discussed.

The nine simulations show that the use of recovered material and alternative fuel (defined waste) can be increased while maintaining the current requirements on clinker performance. An increase in the use of recovered material and alternative fuel replaces the use of resources. The simulations also show that the emissions of $\mathrm{CO}_{2}, \mathrm{NO}_{X}, \mathrm{SO}_{2}, \mathrm{CO}, \mathrm{VOC}, \mathrm{CH}_{4}$ and dust can be reduced between 30 and $80 \%$ depending on the use of recovered material and alternative fuel. The transport of recovered material and alternative fuel increases with increased use. However, the environmental benefits of the increase in use of recovered material and alternative fuel are by far greater than the resource use and emissions to air associated with the increase in transport.
\end{abstract}

(C) 2005 Published by Elsevier Ltd.

\section{Introduction}

The increasing interest in environmental issues and pressure on industries to develop more environmentally adapted products is an additional impetus for product and process development. To support decisions on product and process development options and strategic planning, information on the consequences of planned changes are needed. As a consequence, a life cycle process model has been developed in the cement industry [1]. The model predicts environmental, product and economic performance, from a life cycle perspective, by simulating different operational alternatives for producing cement.

\footnotetext{
* Corresponding author. Tel.: +46862468 22; fax: +46862568 98.

E-mail address: karin.gabel@cementa.se (K. Gäbel).
}

Cementa $\mathrm{AB}$, the cement manufacturer in Sweden, aims to contribute to the development of a sustainable society and has committed itself to set environmental goals annually to achieve continual improvement [2]. To be able to set environmental goals and to take action Cementa needs to simulate development options to generate information on potential product, environmental and economic performance. Some of the interesting future development options are an increase in the use of industrial by-products and defined waste as raw material, fuel and cement additives. In this paper, the current and eight future operational alternatives for producing cement have been simulated, using the life cycle process model [1].

The work presented here has two purposes. One is to find out if the life cycle process model that has been developed can be used for its intended purpose. The other is to explore the potential to minimise negative environmental impact through an increase in the use of 
industrial by-products and defined waste as raw material, fuel and cement additives.

\section{Scenarios simulated}

Industrial by-products can be used either in the raw meal mix or in the cement mix, and defined waste can be used in the fuel mix. In discussion with representatives from different departments at Cementa $A B$, it was agreed that it would be interesting to explore two raw meal mixes, two cement mixes and three fuel mixes. A raw meal mix, a fuel mix and a cement mix were then combined into an operational alternative, a scenario, to be simulated. This section briefly describes the different mixes and how they were combined into nine scenarios.

Industrial by-products (e.g., slag, fly ash, industrial gypsum, and industrial sand) can be used as substitutes for traditional natural raw materials. The recovered materials can either be used as raw material in the raw meal, or in the cement grinding as substitutes for clinker or cement additives. According to the European standard "Cement - Composition, Specifications and Conformity Criteria" [3], a type I cement must contain at least $95 \%$ clinker, a type II cement $80 \%$ clinker, and a type III cement at least $60 \%$ clinker. Different types of defined waste (e.g., used tyres, used plastics, spent solvents, waste oils) that cannot be recycled can instead be used as substitutes for traditional fossil fuel in cement manufacturing.

Cementa currently produces a type II cement in which recovered material is used as cement additives and where limestone replaces part of the clinker. The raw meal mix used today consists of limestone, industrial sand and a small amount of iron oxide. And, today, about $25 \%$ of the fossil fuel is replaced with used tyres. These current mixes were combined and gave an $\mathrm{O}$-scenario.
Cementa's environmental goal for 2003 is to replace at least $40 \%$ of the fossil fuel (by thermal energy content), used at Cementa's three plants in Sweden, with alternative fuel [4]. One future fuel mix to study, subsequently, is to replace $40 \%$ of the fossil fuel. Another interesting fuel mix is to replace $80 \%$ of the fossil fuel. An interesting raw meal mix to study is to replace part of the limestone by recovered material. And, an interesting cement mix to study is a type III cement in which additional clinker is replaced by limestone and recovered material.

The current mixes and future mixes were combined into nine operational alternatives to be simulated, as shown in Table 1.

\section{Method - the life cycle process model}

The model, previously described in Gäbel et al. [1], was used to simulate the scenarios.

To avoid sub-optimisation, the life cycle process model uses a life cycle perspective. The cement manufacturing process, from "cradle to gate", is divided into a foreground system and a background system, shown in Fig. 1. The foreground system represents Cementa's "gate to gate" part of the system. Cementa can, in detail, control and decide on processes in the foreground system, but can only make specifications and requirements on products from the background system. Alternative raw material, cement additives and fuel are by-products or defined waste from other technical systems. The production of these alternative products is not included. However, the additional preparation, handling and transport to make them fit the cement industry are included. Depending on whether or not the additional preparation, handling and transport are done by Cementa, the processes are either in the foreground system or the background system.

Table 1

Operational alternatives to be simulated

\begin{tabular}{|c|c|c|c|}
\hline Scenario & Raw meal mix & Fuel mix & Cement mix \\
\hline $\mathrm{O}$ & $\begin{array}{l}\text { Current; } 93.5 \% \text { limestone and } \\
6.5 \% \text { recovered material }\end{array}$ & $\begin{array}{l}\text { Current; } 25 \% \\
\text { alternative fuels }\end{array}$ & $\begin{array}{l}\text { Current type II; } 84 \% \text { clinker, } 10 \% \\
\text { limestone, } 6 \% \text { recovered material }\end{array}$ \\
\hline A & $\begin{array}{l}\text { Current } ; 93.5 \% \text { limestone and } \\
6.5 \% \text { recovered material }\end{array}$ & $\begin{array}{l}\text { Replace } 40 \% \\
\text { fossil fuel }\end{array}$ & $\begin{array}{l}\text { Current type II; } 84 \% \text { clinker, } 10 \% \\
\text { limestone, } 6 \% \text { recovered material }\end{array}$ \\
\hline B & $\begin{array}{l}\text { Current; } 93.5 \% \text { limestone and } \\
6.5 \% \text { recovered material }\end{array}$ & $\begin{array}{l}\text { Replace } 80 \% \\
\text { fossil fuel }\end{array}$ & $\begin{array}{l}\text { Current type II; } 84 \% \text { clinker, } 10 \% \\
\text { limestone, } 6 \% \text { recovered material }\end{array}$ \\
\hline $\mathrm{C}$ & $\begin{array}{l}\mathbf{8 0} \% \text { limestone, } 20 \% \\
\text { recovered material }\end{array}$ & $\begin{array}{l}\text { Replace } 40 \% \\
\text { fossil fuel }\end{array}$ & $\begin{array}{l}\text { Current type II; } 84 \% \text { clinker, } 10 \% \\
\text { limestone, } 6 \% \text { recovered material }\end{array}$ \\
\hline $\mathrm{D}$ & $\begin{array}{l}80 \% \text { limestone, } 20 \% \\
\text { recovered material }\end{array}$ & $\begin{array}{l}\text { Replace } 80 \% \\
\text { fossil fuel }\end{array}$ & $\begin{array}{l}\text { Current type II; } 84 \% \text { clinker, } 10 \% \\
\text { limestone, } 6 \% \text { recovered material }\end{array}$ \\
\hline $\mathrm{E}$ & $\begin{array}{l}\text { Current; } 93.5 \% \text { limestone and } \\
6.5 \% \text { recovered material }\end{array}$ & $\begin{array}{l}\text { Replace } 40 \% \\
\text { fossil fuel }\end{array}$ & $\begin{array}{l}\text { A type III; } 60 \% \text { clinker, } 15 \% \\
\text { limestone, } 25 \% \text { recovered material }\end{array}$ \\
\hline $\mathrm{F}$ & $\begin{array}{l}\text { Current; } 93.5 \% \text { limestone and } \\
6.5 \% \text { recovered material }\end{array}$ & $\begin{array}{l}\text { Replace } 80 \% \\
\text { fossil fuel }\end{array}$ & $\begin{array}{l}\text { A type } \mathrm{III} ; \mathbf{6 0 \%} \text { clinker, } 15 \% \\
\text { limestone, } 25 \% \text { recovered material }\end{array}$ \\
\hline G & $\begin{array}{l}\mathbf{8 0} \% \text { limestone, } \mathbf{2 0} \% \\
\text { recovered material }\end{array}$ & $\begin{array}{l}\text { Replace } 40 \% \\
\text { fossil fuel }\end{array}$ & $\begin{array}{l}\text { A type III; } 60 \% \text { clinker, } 15 \% \\
\text { limestone, } 25 \% \text { recovered material }\end{array}$ \\
\hline $\mathrm{H}$ & $\begin{array}{l}80 \% \text { limestone, } 20 \% \\
\text { recovered material }\end{array}$ & $\begin{array}{l}\text { Replace } 80 \% \\
\text { fossil fuel }\end{array}$ & $\begin{array}{l}\text { A type III; } 60 \% \text { clinker, } 15 \% \\
\text { limestone, } 25 \% \text { recovered material }\end{array}$ \\
\hline
\end{tabular}




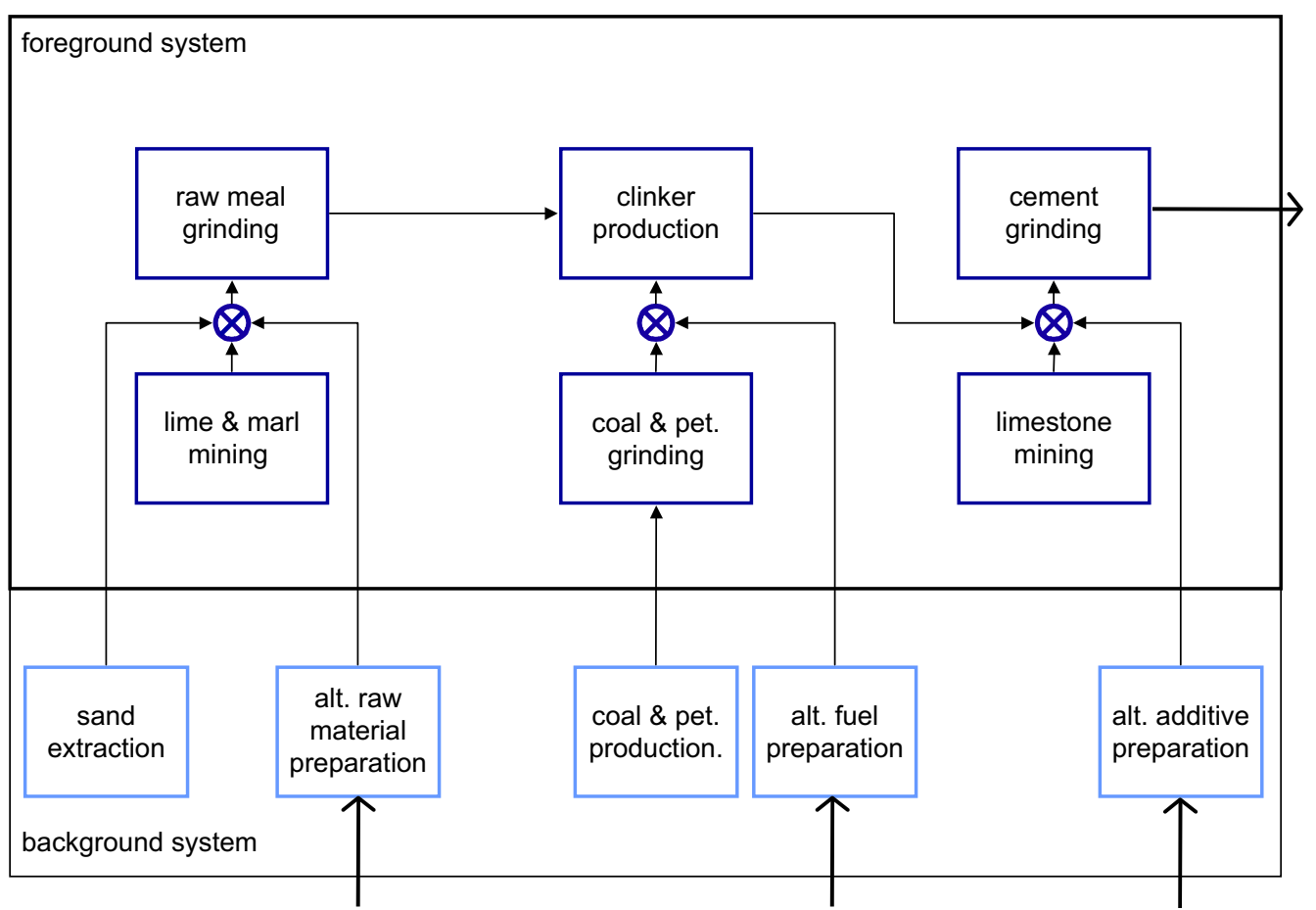

Fig. 1. The life cycle process model.

The foreground and background systems are modelled with different techniques and levels of detail. The foreground system model has been built with techniques as described in Gäbel et al. [1]. The cement manufacturing process, as well as the formulas, relations and data needed to construct the model have been described in Gäbel [5]. The background system has been modelled with normal life cycle inventory (LCI) technique [6] and stored in SPINE format [7].

The reason for the modelling techniques in the foreground system is related to limitations of conventional LCI modelling techniques.

State of the art LCI models are typically used to relate resource use and emission to manufacturing and use of a certain product, or rather the function of a product. Corresponding software tools are generally specialised to perform normalisation of the flow to the functional unit. Current LCI modelling has a limited capability to perform other types of simulations. There are limits in the possibility of changing process variables without changing the underlying model. Making use of a non-causal, physical and object-oriented modelling approach and separating a neutral model from the problem formulation resulted in a flexible foreground system model that can be used to perform different types of simulation and for a number of different purposes.

Another limitation, from an industrial perspective, is that conventional LCI models do not address product performance and economic cost. Product performance and economic cost are taken into account by assigning products entering the foreground system chemical composition and cost. Subsequently, materials entering the foreground system, as well as in the foreground system, are described as total mass flow, chemical composition, thermal energy content and cost. The different process entities in the foreground system model describe the physical and chemical transformation of the flow as well as cumulative production cost.

The foreground system model has been validated for two cases [1] and shows satisfactory agreement with the real system's properties to be used to simulate the desired operational alternatives and to generate the information requested.

To complete the life cycle aspect of the model the foreground system model and the background system model are connected.

The following data sources were used for the background system. Persons at Cementa estimated the potential supplier, manufacturing site, distance and means of transportation for all the supplied material. Data for coal production are the average data used in the European cement industry [8]. Data for petroleum coke production have been taken from a Nordic LCA study on cement and concrete. Data for electricity production are the Swedish average electricity data supplied by the Centre for Environmental Assessment of Product and Material Systems (CPM) [10]. Data for transport are the average data for transport based on Swedish conditions and based on the fleet in 1999 supplied by the Centre for Environmental Assessment of Product and Material Systems (CPM) [11]. 
The model is a life cycle inventory model and for each simulated operational alternative, the environmental load as specified in Table 2 was calculated. No impact assessment was done, which means that the result is presented as inventory parameters. The composition of the exhaust gas from clinker production $(\mathrm{kg} / \mathrm{ton}$ cement), and the electrical and thermal energy use $(\mathrm{MJ} /$ ton cement) in the foreground system were calculated separately. The composition of all intermediate products, e.g. raw meal and clinker, and cement was calculated. In addition, the material and production cost ("SEK"/ton cement) was calculated, although not presented in this paper.

The parameters describing the environmental load were selected on two grounds. They contribute to largescale environmental problems. And they could be modelled with an acceptable degree of uncertainty, since the variation of the compounds in the raw material and fuel that give rise to the environmental load is minor.

Naturally, there are also other types of environmental load that could be considered. Among those are very local ones, such as noise, vibrations and odour. The emission of small amounts of toxic substances, such as some metals, dioxins and furans has not been modelled due to large uncertainties. These emissions depend, to a large degree, on minor variations in raw material and fuel composition. Moreover, there is a limited amount of empirical data available to model the formation of these emissions.

\section{Problem formulation}

The life cycle process model is flexible. It can either from given product performance requirements, calculate the raw meal mix, or from given raw meal mix, calculate potential product performance. Thus, it is a neutral model and does not include any specific problem to be

Table 2

Parameters used to describe environmental load

Resource use
Natural mineral resource
Fossil fuel
Bio-fuel
Uranium ore
Area
Water
Non elementary in-flow, "flows not followed to the cradle"
Recovered material
Alternative fuel
Emission to air
$\mathrm{CO}_{2}$, carbon dioxide
$\mathrm{NO}_{X}$, nitrogen oxides $\left(\mathrm{NO}\right.$ and $\mathrm{NO}_{2}$ as $\left.\mathrm{NO}_{2}\right)$
$\mathrm{SO}_{2}$, sulphur dioxide
$\mathrm{CO}_{\text {, carbon monoxide }}$
$\mathrm{VOC}$, volatile organic compounds
$\mathrm{CH}_{4}$, methane
Dust

solved [1]. For each scenario simulated, the specific problem was formulated separately and added, as outlined in the following.

Each operational alternative and potential product have to be assessed in relation to the most important feasibility criteria, product performance. Product performance is described with three ratios used in the cement industry: the lime saturation factor (LSF), the silica ratio (SR), and the alumina ratio (AR). The ratios describe the relation between the four main components in the raw meal, clinker or cement, and are shown in Table 3.

For the simulated operational alternatives in which the current raw meal mix was used (scenarios $\mathrm{O}, \mathrm{A}, \mathrm{B}, \mathrm{E}$ and $F$ ), the percentage of each raw material in the raw meal mix, each fuel in the fuel mix, and each cement additive in the cement mix was given. The model calculated the raw meal, clinker and cement composition and performance. The calculated clinker quality factors, LSF, SR and AR, were assessed according to given criteria.

For the operational alternatives in which part of the limestone in the raw meal is replaced by recovered material (scenarios $\mathrm{C}, \mathrm{D}, \mathrm{G}$ and $\mathrm{H}$ ), the available raw material in the raw meal mix was given together with the clinker quality factors, LSF, SR and AR. The percentage of each fuel in the fuel mix, and each cement additive in the cement mix were given. The model calculated the percentage of each raw material in the raw meal mix and raw meal, as well as the clinker- and cement composition and performance.

The problem formulations for each scenario, in terms of which parameters to lock and the value with which to designate each of them, are presented in Table 4.

\section{Results}

The environmental load and cost of future operational alternatives have to be related to feasible operational alternatives and products. Product performance is, in this case, used to determine whether or not an operational alternative is feasible. The calculated potential clinker quality factors, LSF, SR and AR for the nine operational alternatives, are presented in Fig. 2.

Table 3

Product performance (cement-, clinker-, raw meal ratios)

\begin{tabular}{|c|c|c|}
\hline Ratio & Denomination & Formula \\
\hline $\begin{array}{l}\text { Lime saturation } \\
\text { factor }\end{array}$ & LSF & $\begin{array}{l}\mathrm{LSF}=(100 \mathrm{CaO}) /\left(2.8 \mathrm{SiO}_{2}+\right. \\
\left.1.1 \mathrm{Al}_{2} \mathrm{O}_{3}+0.7 \mathrm{Fe}_{2} \mathrm{O}_{3}\right)\end{array}$ \\
\hline Silica ratio & SR & $\mathrm{SR}=\left(\mathrm{SiO}_{2}\right) /\left(\mathrm{Al}_{2} \mathrm{O}_{3}+\mathrm{Fe}_{2} \mathrm{O}_{3}\right)$ \\
\hline Alumina ratio & AR & $\mathrm{AR}=\left(\mathrm{Al}_{2} \mathrm{O}_{3}\right) /\left(\mathrm{Fe}_{2} \mathrm{O}_{3}\right)$ \\
\hline
\end{tabular}


Table 4

Scenario description and problem formulation

\begin{tabular}{lr}
\hline Scenario $O$ & \\
Raw meal mix, current & \\
\hline Limestone & $93.5 \%$ \\
Sand & $6.0 \%$ \\
Iron oxide & $0.5 \%$
\end{tabular}

Scenario A

Raw meal mix, current

\begin{tabular}{lr}
\hline Limestone & $93.6 \%$ \\
Sand & $6.0 \%$ \\
Iron oxide & $0.4 \%$
\end{tabular}

Scenario B

Raw meal mix, current

\begin{tabular}{lr}
\hline Limestone & $93.6 \%$ \\
Sand & $6.0 \%$ \\
Iron oxide & $0.4 \%$
\end{tabular}

Scenario $C$

Raw material in raw meal

$\begin{array}{ll}\text { Limestone } & 80.0 \%\end{array}$

Industrial sand

Slag

Fly ash

Clinker quality factor

$\begin{array}{lr}\text { LSF } & 100.0 \\ \text { SR } & 3.0 \\ \text { AR } & 1.6\end{array}$

Scenario D

Raw material in raw meal

\begin{tabular}{ll}
\hline Limestone & $80.0 \%$
\end{tabular}

Industrial sand

Slag

Fly ash

Clinker quality factor

$\begin{array}{lr}\text { LSF } & 100.0 \\ \text { SR } & 3.0 \\ \text { AR } & 1.6\end{array}$

Scenario E

Raw meal mix, current

\begin{tabular}{lr}
\hline Limestone & $93.6 \%$ \\
Sand & $6.0 \%$ \\
Iron oxide & $0.4 \%$
\end{tabular}

Scenario $F$

Raw meal mix, current

\begin{tabular}{lr}
\hline Limestone & $93.6 \%$ \\
Sand & $6.0 \%$ \\
Iron oxide & $0.4 \%$
\end{tabular}

Fuel mix, 25\% alternative fuel

\begin{tabular}{ll}
\hline Coal & $52.5 \%$ \\
Petroleum coke & $22.5 \%$ \\
Tyres & $25.0 \%$
\end{tabular}

Fuel mix, $40 \%$ alternative fuel

\begin{tabular}{ll}
\hline Coal & $42.0 \%$ \\
Petroleum coke & $18.0 \%$ \\
Tyres & $30.0 \%$ \\
Plastic & $10.0 \%$
\end{tabular}

Fuel mix, $80 \%$ alternative fuel

\begin{tabular}{lr}
\hline Coal & $14.0 \%$ \\
Petroleum coke & $6.0 \%$ \\
Tyres & $37.5 \%$ \\
Plastic & $10.0 \%$ \\
liquid & $32.5 \%$
\end{tabular}

Fuel mix, $40 \%$ alternative fuel

\begin{tabular}{ll}
\hline Coal & $42.0 \%$ \\
Petroleum coke & $18.0 \%$ \\
Tyres & $30.0 \%$ \\
Plastic & $10.0 \%$
\end{tabular}

Fuel mix, $80 \%$ alternative fuel

\begin{tabular}{lr}
\hline Coal & $14.0 \%$ \\
Petroleum coke & $6.0 \%$ \\
Tyres & $37.5 \%$ \\
Plastic & $10.0 \%$ \\
Liquid & $32.5 \%$
\end{tabular}

Fuel mix, $40 \%$ alternative fuel

\begin{tabular}{ll}
\hline Coal & $42.0 \%$ \\
Petroleum coke & $18.0 \%$ \\
Tyres & $30.0 \%$ \\
Plastic & $10.0 \%$
\end{tabular}

Fuel mix, $80 \%$ alternative fuel

\begin{tabular}{lr}
\hline Coal & $14.0 \%$ \\
Petroleum coke & $6.0 \%$ \\
Tyres & $37.5 \%$ \\
Plastic & $10.0 \%$ \\
Liquid & $32.5 \%$
\end{tabular}

Cement mix, type II

\begin{tabular}{lr}
\hline Clinker & $84.0 \%$ \\
Limestone & $10.0 \%$ \\
Gypsum & $4.0 \%$ \\
Slag & $2.0 \%$
\end{tabular}

Cement mix, type II

\begin{tabular}{lr}
\hline Clinker & $84.0 \%$ \\
Limestone & $10.0 \%$ \\
Gypsum & $4.0 \%$ \\
Slag & $2.0 \%$
\end{tabular}

Cement mix, type II

\begin{tabular}{lr}
\hline Clinker & $84.0 \%$ \\
Limestone & $10.0 \%$ \\
Gypsum & $4.0 \%$ \\
Slag & $2.0 \%$
\end{tabular}

Cement mix, type II

\begin{tabular}{lr}
\hline Clinker & $84.0 \%$ \\
Limestone & $10.0 \%$ \\
Gypsum & $4.0 \%$ \\
Slag & $2.0 \%$
\end{tabular}

Cement mix, type II

\begin{tabular}{lr}
\hline Clinker & $84.0 \%$ \\
Limestone & $10.0 \%$ \\
Gypsum & $4.0 \%$ \\
Slag & $2.0 \%$
\end{tabular}

Cement mix, type III

\begin{tabular}{lr}
\hline Clinker & $60.0 \%$ \\
Limestone & $15.0 \%$ \\
Gypsum & $5.0 \%$ \\
Slag & $20.0 \%$ \\
& \\
& \\
Cement mix, type III & \\
\hline Clinker & $60.0 \%$ \\
Limestone & $15.0 \%$ \\
Gypsum & $5.0 \%$ \\
Slag & $20.0 \%$
\end{tabular}


Table 4 (continued)

\begin{tabular}{|c|c|c|c|c|c|}
\hline \multicolumn{6}{|c|}{ Scenario $G$} \\
\hline Limestone & $80.0 \%$ & Coal & $42.0 \%$ & Clinker & $60.0 \%$ \\
\hline Industrial sand & & Petroleum coke & $18.0 \%$ & Limestone & $15.0 \%$ \\
\hline Slag & & Tyres & $30.0 \%$ & Gypsum & $5.0 \%$ \\
\hline Fly ash & & Plastic & $10.0 \%$ & Slag & $20.0 \%$ \\
\hline \multicolumn{6}{|c|}{ Clinker quality factor } \\
\hline LSF & 100.0 & & & & \\
\hline SR & 3.0 & & & & \\
\hline $\mathrm{AR}$ & 1.6 & & & & \\
\hline \multicolumn{6}{|l|}{ Scenario $H$} \\
\hline \multicolumn{2}{|c|}{ Raw material in raw meal } & \multicolumn{2}{|c|}{ Fuel mix, $80 \%$ alternative fuel } & \multicolumn{2}{|c|}{ Cement mix, type III } \\
\hline Limestone & $80.0 \%$ & Coal & $14.0 \%$ & Clinker & $60.0 \%$ \\
\hline Industrial sand & & Petroleum coke & $6.0 \%$ & Limestone & $15.0 \%$ \\
\hline Slag & & Tyres & $37.5 \%$ & Gypsum & $5.0 \%$ \\
\hline Fly ash & & Plastic & $10.0 \%$ & Slag & $20.0 \%$ \\
\hline & & Liquid & $32.5 \%$ & & \\
\hline \multicolumn{6}{|c|}{ Clinker quality factor } \\
\hline LSF & 100.0 & & & & \\
\hline SR & 3.0 & & & & \\
\hline $\mathrm{AR}$ & 1.6 & & & & \\
\hline
\end{tabular}

The current range within which the LSF, SR and AR may vary is presented in Table 5 .

The three clinker quality factors of scenarios C, D, G and $\mathrm{H}$ are given in the problem formulation. Even the calculated clinker quality factors of the other five scenarios, $\mathrm{O}, \mathrm{A}, \mathrm{B}, \mathrm{E}$ and $\mathrm{F}$, are within the given range. All scenarios are feasible in relation to current requirements on clinker performance.

\subsection{Resource use}

Figs. 3 and 4 show the resource use, per $1000 \mathrm{~kg}$ cement, in scenarios $\mathrm{O}-\mathrm{H}$. The use of natural mineral resource $(\mathrm{kg})$ and recovered material $(\mathrm{kg})$ is presented in Fig. 3, and energy resources in Fig. 4.

Natural mineral resources and recovered material are only used in the foreground system. Naturally, an increase in the use of recovered material in both the raw meal mix and the cement mix replaces the use of natural mineral resources. In addition, total use of material is reduced with an increase in the use of recovered material. To produce $1 \mathrm{~kg}$ of clinker, approximately $1.6 \mathrm{~kg}$ of raw meal is needed. This is due to the fact that in the clinker production process, the limestone is decomposed into $\mathrm{CO}_{2}$ and reactive $\mathrm{CaO}$. Subsequently, the loss of material is lower when the cement contains $60 \%$ clinker (scenarios E, F, G and $\mathrm{H}$ ), compared with $84 \%$ clinker (scenarios $\mathrm{O}$, A, B, C and D). When recovered material replaces parts of the limestone in the raw meal (scenarios $\mathrm{C}, \mathrm{D}, \mathrm{G}$ and $\mathrm{H}$ ), calcined $\mathrm{CaO}$ is introduced to the clinker production process. This explains the minor reduction in material use in these scenarios, as compared with scenarios in which
$\mathrm{CaO}$ originates only from limestone (scenarios $\mathrm{O}, \mathrm{A}, \mathrm{B}, \mathrm{E}$ and F).

Bio-fuel, uranium ore and area are only used in electricity production, which is in the background system. The uranium ore used has a content of $\mathrm{U}_{3} \mathrm{O}_{8}$ of $2.22 \%$. The use of bio-fuel, uranium and area is reduced from scenario $\mathrm{O}$ to scenario $\mathrm{G}$, as the demand for electricity decreases.

Fossil fuel is used in both the foreground system and the background system, but most of all in the foreground. The fossil fuel use in the background system is presented in more detail in Section 5.4.

In the foreground system, fossil fuel is used in the clinker production process. Alternative fuel is used in the foreground system as a substitute for fossil fuel. Naturally, when the use of alternative fuel increases the use of fossil fuel is reduced by the same amount. There is also a reduction in the total fuel use in the foreground system from scenario $\mathrm{O}$ to scenario $\mathrm{H}$.

The foreground system energy diagram, Fig. 5, shows the relative thermal and electrical energy used by the foreground system per $1000 \mathrm{~kg}$ cement.

The use of thermal energy decreases with an increase in the use of recovered material, both in the cement mix and the raw meal mix. The thermal energy use is lower for cement with $60 \%$ clinker (scenarios $\mathrm{E}, \mathrm{F}, \mathrm{G}$ and $\mathrm{H}$ ) compared with cement with $84 \%$ clinker (scenarios $\mathrm{O}$, $\mathrm{A}, \mathrm{B}, \mathrm{C}$ and $\mathrm{D}$ ). When more clinker is replaced with limestone and recovered material, less clinker has to be produced and naturally, less thermal energy is needed.

The thermal energy use is also lower when recovered material replaces part of the limestone in the raw meal 


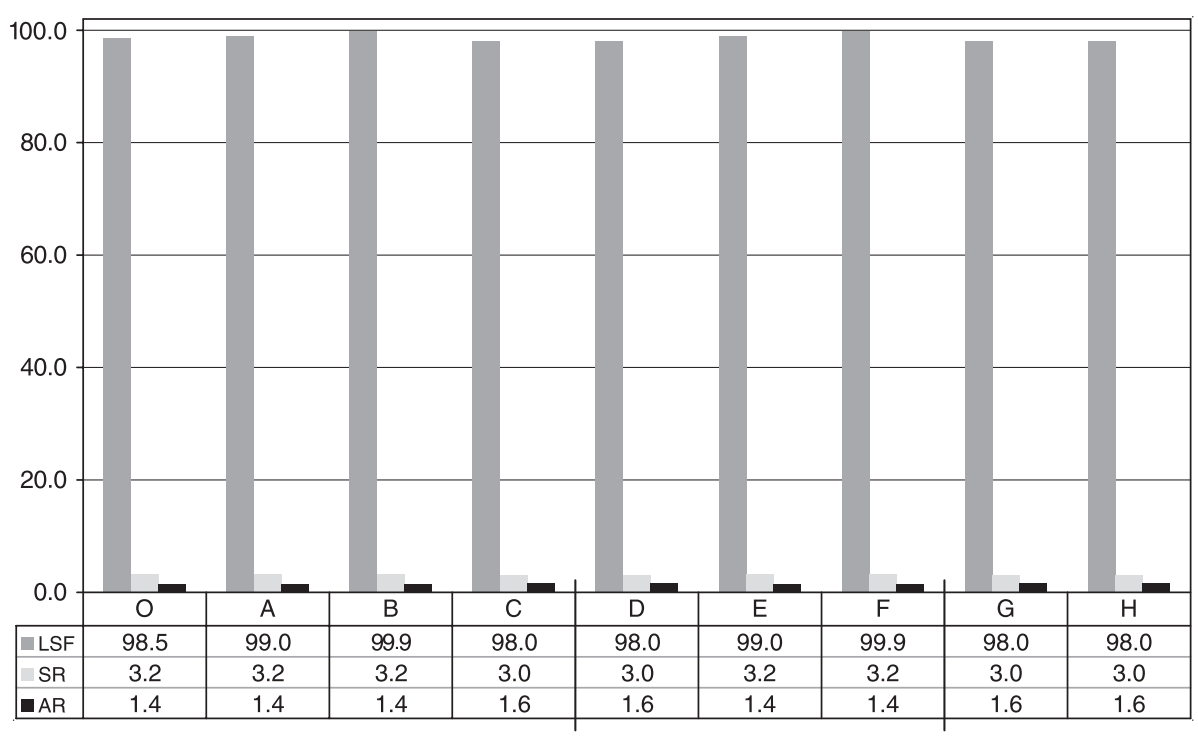

Fig. 2. Potential clinker quality factors, scenarios $\mathrm{O}-\mathrm{H}$.

(scenarios $\mathrm{C}, \mathrm{D}, \mathrm{G}$ and $\mathrm{H}$ ), compared with when current raw meal is used (scenarios $\mathrm{O}, \mathrm{A}, \mathrm{B}, \mathrm{E}$ and $\mathrm{F}$ ). The calcination process, i.e., the thermal decomposition of $\mathrm{CaCO}_{3}$ leaving reactive $\mathrm{CaO}$ and liberating gaseous $\mathrm{CO}_{2}$, is very energy demanding. The recovered material contains $\mathrm{CaO}$, which is already calcined. Thus, when this calcined $\mathrm{CaO}$ replaces carbonatic $\mathrm{CaO}$ in the clinker production process, less thermal energy is used.

The use of thermal energy is not reduced at the expense of an increase in the use of electrical energy. The use of electrical energy is slightly reduced for the scenarios in which the cement contains $60 \%$ clinker (scenarios E, F, G and $\mathrm{H}$ ) compared with those containing $84 \%$ clinker (scenarios O, A, B, C, and D). The clinker production process and raw meal grinding are the main consumers of electrical energy. And, when less clinker and raw meal have to be produced, less electrical energy is used.

\subsection{Emission to air}

Fig. 6 shows the emission to air per $1000 \mathrm{~kg}$ cement in scenarios $\mathrm{O}-\mathrm{H}$.

Emissions of $\mathrm{CO}_{2}$ and dust are mainly from the foreground system. Emissions of $\mathrm{NO}_{X}, \mathrm{SO}_{2}$ and $\mathrm{CO}$ occur in both the foreground and background systems.

Table 5

Current product performance requirements

\begin{tabular}{lc}
\hline Clinker quality factor & Current range \\
\hline LSF & $96-100$ \\
SR & $2.8-3.2$ \\
AR & $1.4-1.8$ \\
\hline
\end{tabular}

Emission of VOC is mainly from, and $\mathrm{CH}_{4}$ only from, the background system.

In the background system, the emission of $\mathrm{CO}$ is mainly caused by electricity production but even to a minor extent by the transport of fossil fuel. The emission of $\mathrm{CO}$ is slightly reduced when the cement contains $60 \%$ clinker (scenarios E, F, G and H) compared with when the cement contains $84 \%$ clinker. The reduction follows the reduction in electrical energy use.

The emissions of $\mathrm{CO}_{2}, \mathrm{NO}_{X}, \mathrm{SO}_{2} \mathrm{VOC}$ and $\mathrm{CH}_{4}$ from the background system will be presented in more detail in Section 5.4.

Emissions to air from the foreground system derive from the clinker production process. The emissions of $\mathrm{NO}_{X}, \mathrm{SO}_{2}$ and dust are related to the amount of clinker produced. Thus, the emissions of $\mathrm{NO}_{X}, \mathrm{SO}_{2}$ and dust are lower for cement with $60 \%$ clinker (scenarios E, F, G and $\mathrm{H}$ ), compared with cement with $84 \%$ clinker (scenarios $\mathrm{O}, \mathrm{A}, \mathrm{B}, \mathrm{C}$ and D). Emissions of $\mathrm{CO}$ and VOC are slightly lower when recovered material replaces part of the limestone in the raw meal (scenarios C, D, G and $\mathrm{H}$ ), compared with when current raw meal is used (scenarios O, A, B, E and F). Emissions of CO and VOC are related to the content of organic material in the raw material. The recovered material does not contain any organic material, as does the limestone.

The emission of $\mathrm{CO}_{2}$ originates in the calcination of the raw material and the combustion of fuel. Fig. 7 shows the contribution of raw material, fossil fuel and alternative fuel to $\mathrm{CO}_{2}$ emission. The results have been normalised to the $\mathrm{CO}_{2}$ emission from raw material in scenario $\mathrm{O}$.

The emission of $\mathrm{CO}_{2}$ from the calcination of raw meal is reduced with an increase in the use of recovered material, both in the raw meal and cement mix. The $\mathrm{CO}_{2}$ 


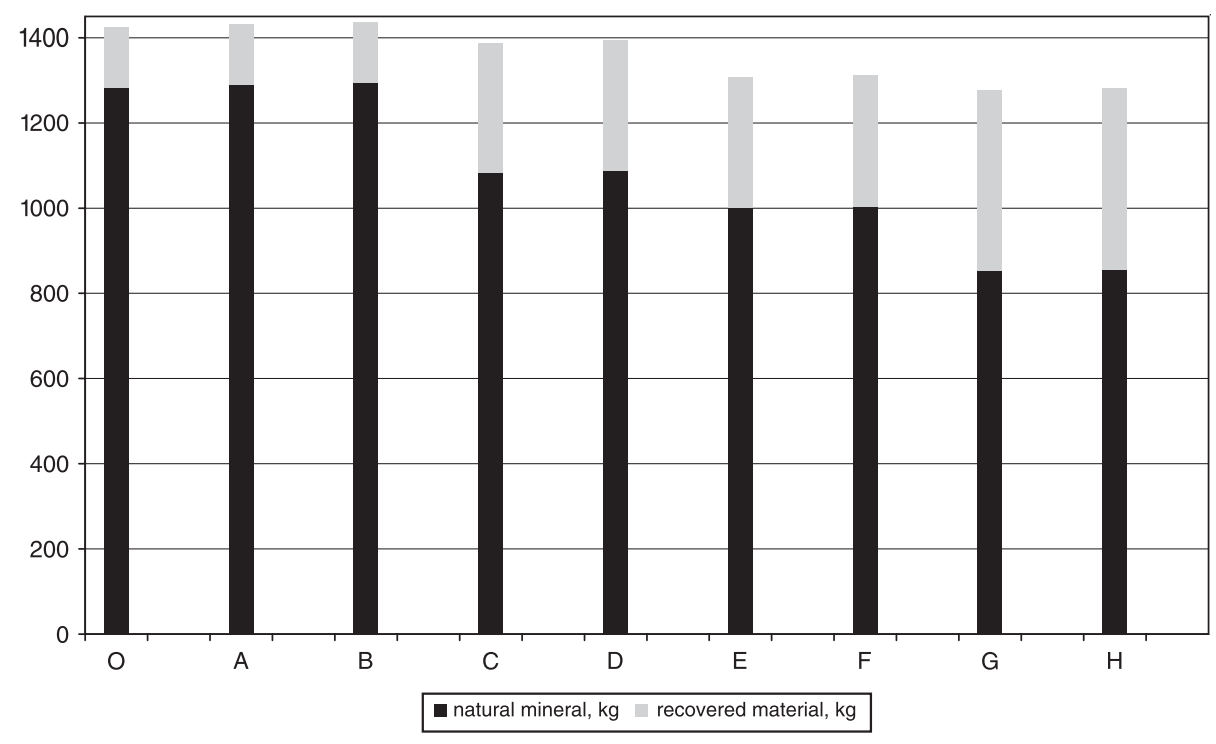

Fig. 3. Use of natural mineral and recovered material in the foreground system, scenarios $\mathrm{O}-\mathrm{H}$.

emission is lower for cement with $60 \%$ clinker (scenarios E, F, G and H), compared with cement with $84 \%$ clinker (scenarios O, A, B, C and D). When more clinker is replaced with limestone and recovered material, less clinker has to be produced, and naturally, less $\mathrm{CO}_{2}$ is released. The emission of $\mathrm{CO}_{2}$ from the raw material is also lower, when recovered material replaces part of the limestone in raw meal (scenarios C, D, G and $\mathrm{H}$ ), compared with when current raw meal is used (scenarios $\mathrm{O}, \mathrm{A}, \mathrm{B}, \mathrm{E}$ and $\mathrm{F}$ ). The recovered material contains $\mathrm{CaO}$ which has already been calcined. Subsequently, when this calcined $\mathrm{CaO}$ replaces carbonatic $\mathrm{CaO}$ in the limestone, less $\mathrm{CO}_{2}$ is released.

When the use of alternative fuel increases from $25 \%$ (scenario $\mathrm{O}$ ) to $40 \%$ (scenarios $\mathrm{A}, \mathrm{C}, \mathrm{E}$ and $\mathrm{G}$ ) and further to $80 \%$ (scenarios $\mathrm{B}, \mathrm{D}, \mathrm{F}$ and $\mathrm{H}$ ) $\mathrm{CO}_{2}$ emission originating in fossil fuel is replaced by $\mathrm{CO}_{2}$ originating from alternative fuel. The $\mathrm{CO}_{2}$ emission from fuel, both fossil and alternative, decreases with a decrease in the use of thermal energy.

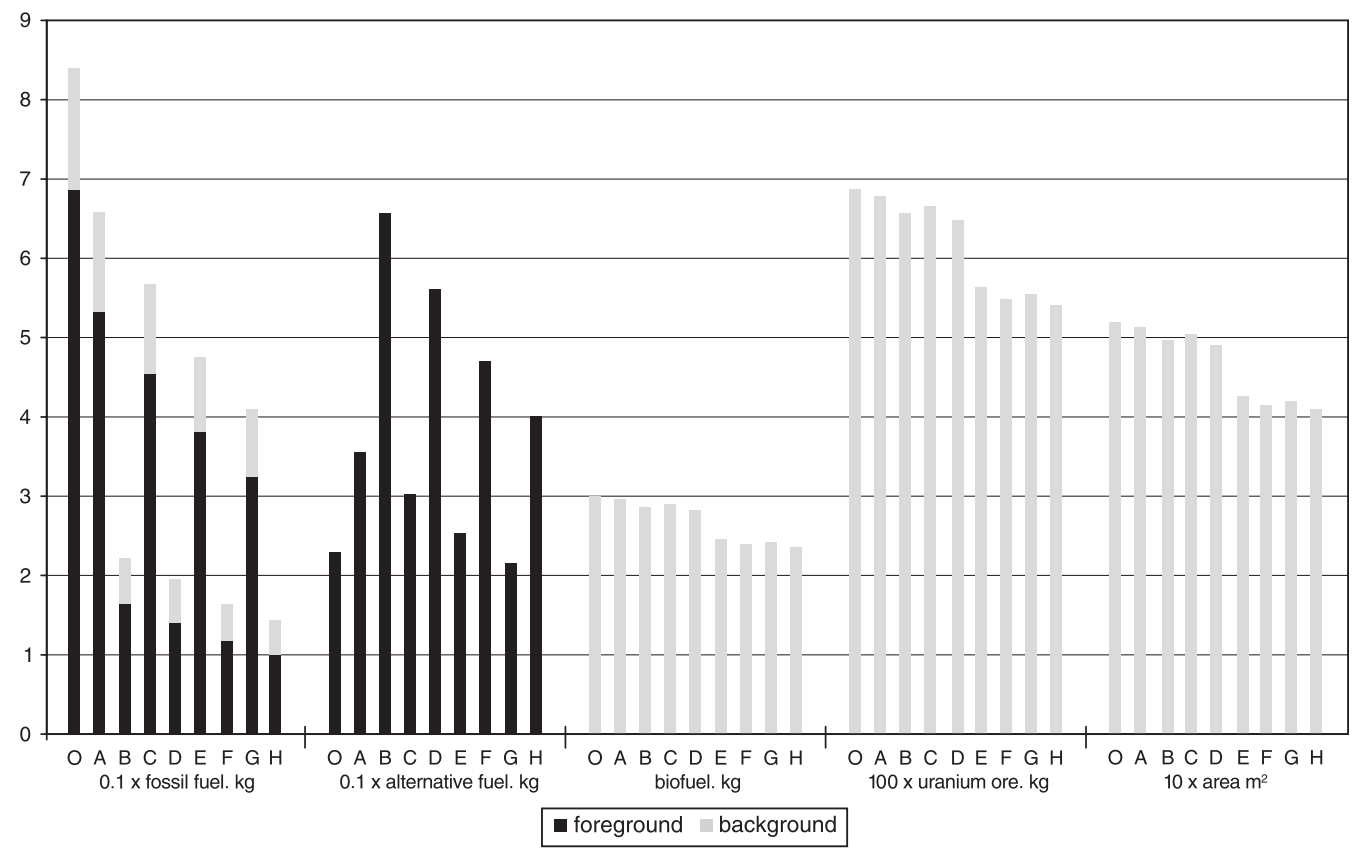

Fig. 4. Resource use in the background and foreground systems, scenarios $\mathrm{O}-\mathrm{H}$. For each category, the bar for each scenario is divided into the use in the foreground system and the use in the background system. Note that different scales are used for different parameters. In order to be able to represent all parameters in the same diagram their values have been multiplied with factors ranging from 0.1 to 100 , as shown in the figure. 


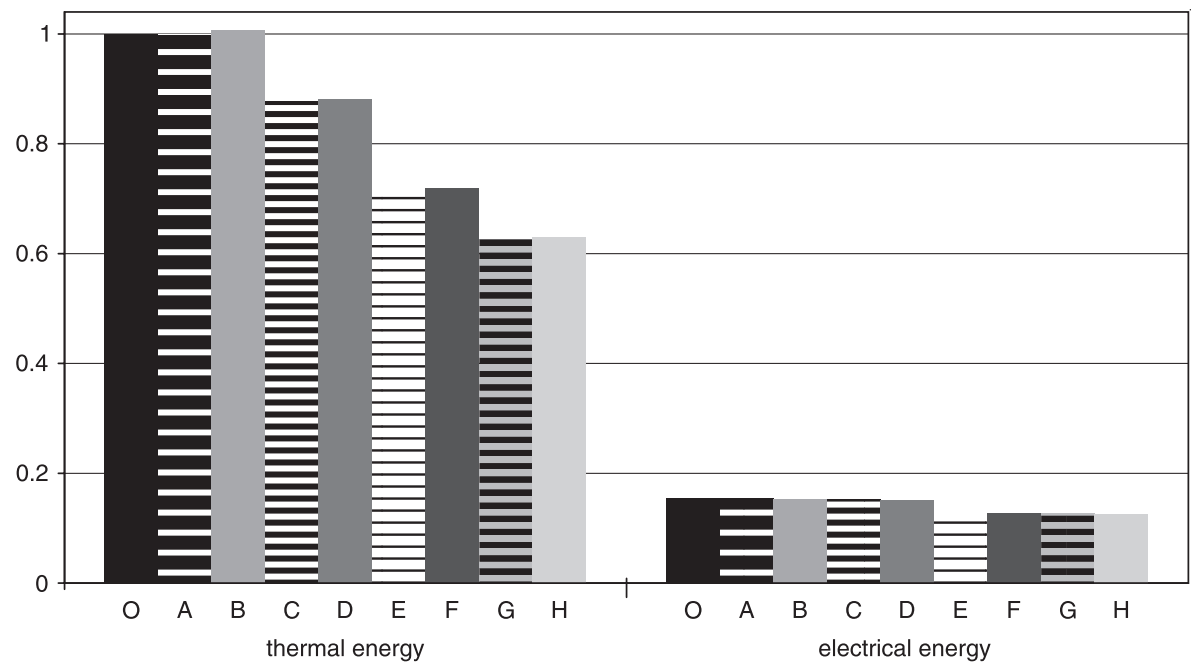

Fig. 5. Thermal and electrical energy use in the foreground system, scenarios $\mathrm{O}-\mathrm{H}$. The thermal and electrical energy use in scenarios $\mathrm{O}-\mathrm{H}$ is shown in relation to the thermal energy use in scenario $\mathrm{O}$.

\subsection{Waste generation}

Electricity production, in the background system, is the only process, which generates any waste. Electricity production generates active radioactive waste and rest other material. The waste generation is reduced in scenarios $\mathrm{O}-\mathrm{H}$, with reduced electrical energy use.

\subsection{Fossil fuel use and emission to air from background system}

This section presents the contribution of the background system to fossil fuel use and emission to air. Electricity production is, however, not included since the contribution of electricity production is low compared with the contribution of other background

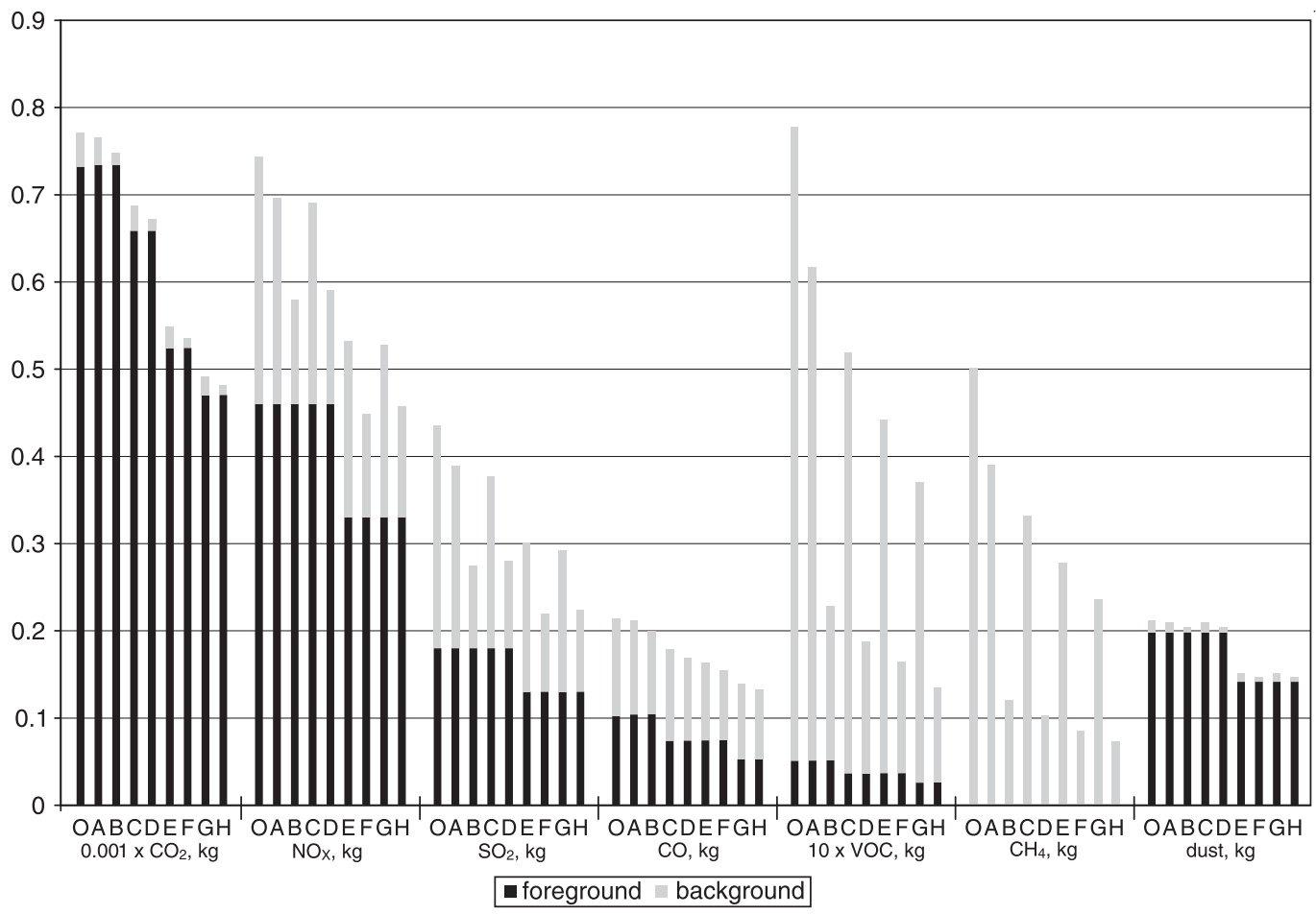

Fig. 6. Emission to air from background and foreground systems, scenarios $\mathrm{O}-\mathrm{H}$. The bar for each scenario is divided into the emission from the foreground system and the emission from the background system. Note that different scales are used for different parameters. In order to be able to represent all parameters in the same diagram their values have been multiplied with factors ranging from 0.001 to 10 , as shown in the figure. 


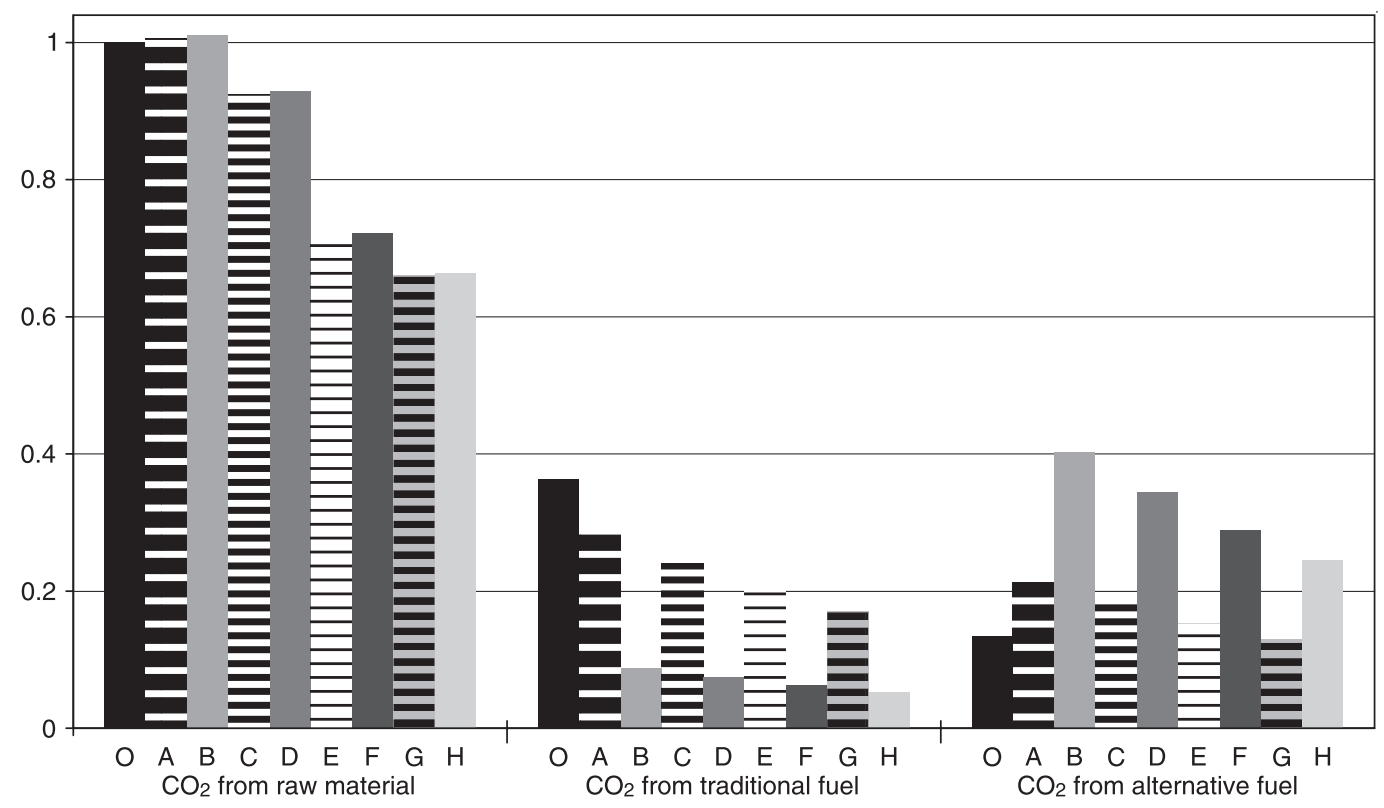

Fig. 7. Relative background system contribution to $\mathrm{CO}_{2}$ emission, scenarios $\mathrm{O}-\mathrm{H}$. The $\mathrm{CO}_{2}$ emissions in scenarios $\mathrm{O}-\mathrm{H}$ are shown in relation to the $\mathrm{CO}_{2}$ emission from the calcinations of the raw material.

processes. In addition, electrical energy use does not vary much in the different scenarios. Fossil fuel production and fossil fuel transport are the two main contributors. It is shown that an increase in the use of recovered material and defined waste reduces resource use and emission to air even in the background system.

Fig. 8 shows the use of fossil fuel and emissions of $\mathrm{CO}_{2}, \mathrm{NO}_{X}, \mathrm{SO}_{2}, \mathrm{VOC}$ and $\mathrm{CH}_{4}$ from the production of fossil fuel, the transport of fossil fuel, the transport of alternative fuel and the transport of recovered material in scenarios $\mathrm{O}-\mathrm{H}$.

Fossil fuel is used mainly in the production of fossil fuel and the transport of fossil fuel and even in the transport of alternative fuel and recovered material. Emissions of $\mathrm{CO}_{2}, \mathrm{NO}_{X}$, and $\mathrm{SO}_{2}$ are mainly due to the production of fossil fuel and transport of fossil fuel, and even the transport of alternative fuel, and the transport of recovered material. VOC is emitted mainly from the production of coal and petroleum coke, and from the transport of coal by train and the emission of $\mathrm{CH}_{4}$ comes from the production of coal and the transport of coal by train.

An increase in the use of alternative fuel, from $25 \%$ (scenario O) to $40 \%$ (A, C, E and G) and further to $80 \%$ $(\mathrm{B}, \mathrm{D}, \mathrm{F}$ and $\mathrm{H})$, reduces the use of fossil fuel and emissions of $\mathrm{CO}_{2}, \mathrm{NO}_{X}, \mathrm{SO}_{2}, \mathrm{VOC}$ and $\mathrm{CH}_{4}$. The use and emissions from the production and transport of fossil fuel are greatly reduced. At the same time, the use of fossil fuel and the emission of $\mathrm{CO}_{2}, \mathrm{NO}_{X}$, and $\mathrm{SO}_{2}$ caused by the transport of alternative fuel are slightly increased. However, the reduction, due to fossil fuel production and transport, is by far greater than the increase associated with the transport of alternative fuel.
In addition, fossil fuel use and corresponding emissions of $\mathrm{CO}_{2}, \mathrm{NO}_{X}, \mathrm{SO}_{2}$, VOC and $\mathrm{CH}_{4}$ decrease with a decrease in the use of thermal energy. Thermal energy use decreases with an increase in the use of recovered material, both in raw meal and cement mix. Lower thermal energy use means lower fuel use, which in turn, results in lower fossil fuel use and emission from the production of fossil fuel and transport of fossil and alternative fuels.

Nevertheless, an increase in the use of recovered material in raw meal, as well as cement mix results in more material transports. This, in turn, results in an increase in fossil fuel use and emissions of $\mathrm{CO}_{2}, \mathrm{NO}_{X}$, and $\mathrm{SO}_{2}$. However, the increase caused by the transport of recovered material is by far lower than the benefits of an increase in the use of recovered material in the foreground system.

\section{Discussion and conclusion}

One purpose was to find out if the life cycle model can be used as its intended. The model was designed and built based on the commissioner's needs and requirements. The model was developed because there was a need to test different combinations of raw material, fuel and cement additives. And, to generate information on potential product performance and environmental and economic consequences for all tested combinations. The generated information was to be assessed in relation to feasibility criteria. The model was developed to support decisions on product and process development. 


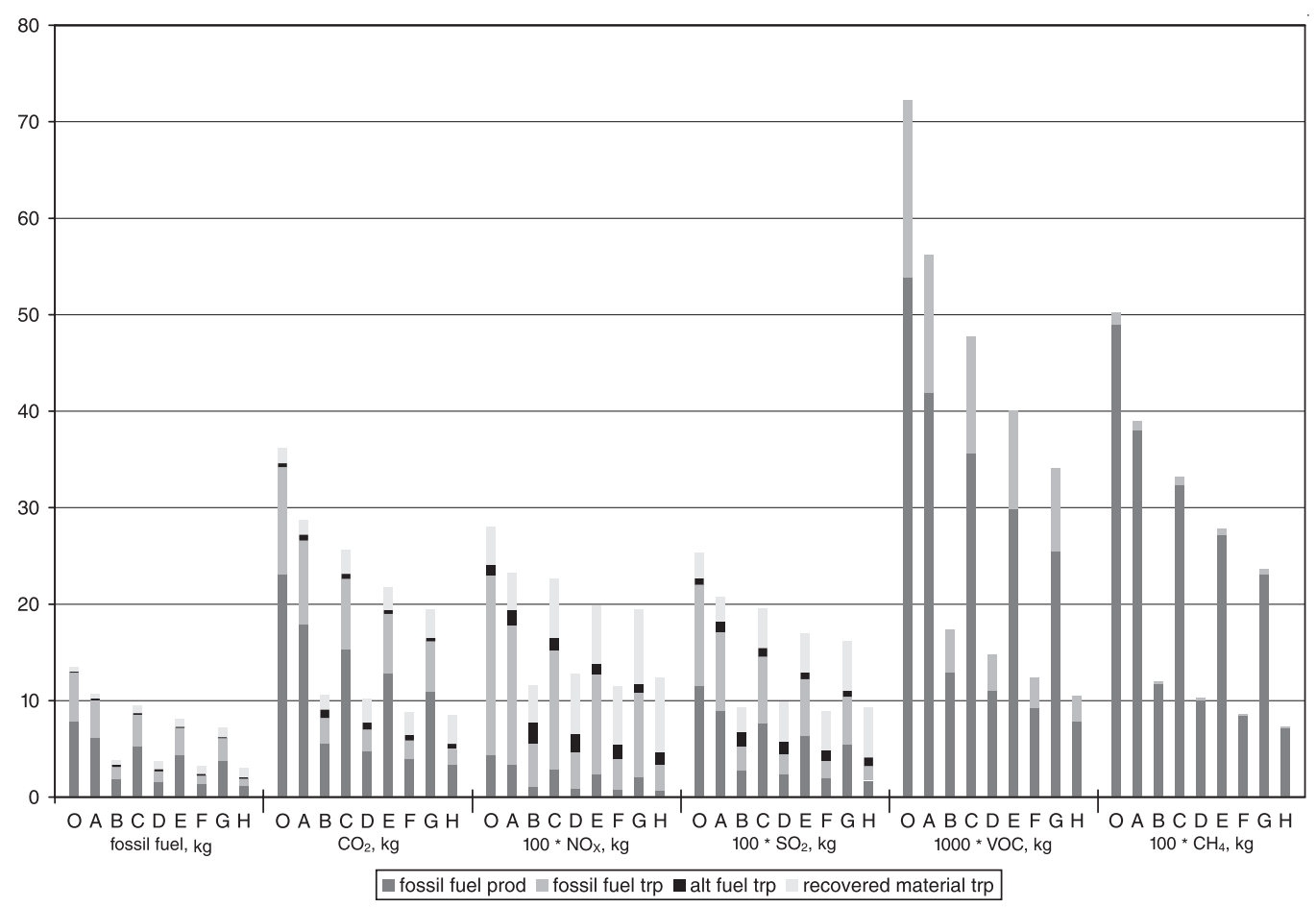

Fig. 8. Fossil fuel use and emission of $\mathrm{CO}_{2}, \mathrm{NO}_{X}, \mathrm{SO}_{2}$, $\mathrm{VOC}$ and $\mathrm{CH}_{4}$ from production of fossil fuel, the transport of fossil fuel, the transport of alternative fuel and the transport of recovered material, scenarios $\mathrm{O}-\mathrm{H}$. For each scenario the bar is divided into the contributing processes. Note that different scales are used for different parameters. In order to be able to represent all parameters in the same diagram their values have been multiplied with factors ranging from 1 to 1000 , as shown in the figure.

It has been shown that the model can simulate different operational alternatives for producing cement. The desired information is generated and assessed in relation to current requirements on product performance. The generated information can be used to give indications for interesting development options for further investigation and study.

The simulations show that the use of recovered material and defined waste can be increased while maintaining the current requirements on clinker performance. An increase in the use of recovered material and alternative fuel replaces the use of virgin resources. They also show that the studied emissions to air can be reduced. An increase in the use of recovered material and alternative fuel causes an increase in transportation, and the associated environmental load. However, these are by far out-weighed by a decrease in the environmental load in cement production.

An increase in the use of recovered material and defined waste has different consequences depending on whether these are used in the fuel mix, in the cement mix or in the raw meal mix. The main environmental consequences, for the three different options, are presented in the following.

An increase in the use of alternative fuel reduces the use of fossil fuel. With an increase in the use of alternative fuel follows an increase in the transport of alternative fuel and a decrease in the production and transport of fossil fuel. Even when $80 \%$ of the fossil fuel is replaced by alternative fuel, the increase in environmental load associated with alternative fuel transport is lower than the decrease associated with fossil fuel production and transport. When alternative fuel is used instead of fossil, the emission of $\mathrm{CO}_{2}$ from fossil fuel is replaced by $\mathrm{CO}_{2}$ from alternative fuel.

An increase in the use of recovered material both replaces the use of natural mineral resources and reduces the total use of raw material. With an increase in the use of recovered material follows a decrease in the emission of $\mathrm{CO}_{2}$ originating in the raw material. The reduction in $\mathrm{CO}_{2}$ emission is larger when recovered material replaces clinker in the cement mix, compared with when it replaces part of the limestone in raw meal. A reduction in emissions of $\mathrm{NO}_{X}$ and $\mathrm{SO}_{2}$ also results with an increase in the use of recovered material in cement mix. And, a reduction in the emission of $\mathrm{CO}$ and $\mathrm{VOC}$ results with an increase in the use of recovered material in raw meal.

The use of thermal energy is also reduced with an increase in the use of recovered material. A reduction in the use of fuel, in turn, results both in a reduction in the emission of $\mathrm{CO}_{2}$ from fuel combustion, and in a reduction of the environmental load from the production and transport of fuels. The use of electrical energy is slightly reduced with an increase in the use of recovered material in the cement mix. 
Which of the three options explored that increased the use of alternative fuel in the fuel mix, increased the use of recovered material in the raw meal mix, or increased the use of recovered material in the cement mix, has the most potential to reduce negative environmental impact?

The following discussion and ranking of alternatives is centred on $\mathrm{CO}_{2}$, which is a major concern for the cement industry. In addition, thermal energy use is used as an indicator of other emissions to the air.

It is not obvious that $\mathrm{CO}_{2}$ from different sources should be valued in the same way when different options are ranked. $\mathrm{CO}_{2}$ from fossil fuel is indisputably an environmental problem. The valuation of $\mathrm{CO}_{2}$ from alternative fuel depends on assumptions made about how the waste would have been treated otherwise. $\mathrm{CO}_{2}$ from raw material is, to some extent, retrieved as concrete in carbonating, i.e. $\mathrm{CO}_{2}$ in the air, reacts and combines with concrete. However, knowledge of the degree and time scale at which the carbonating occurs is limited.

If the emission of $\mathrm{CO}_{2}$ from alternative fuel is valued lower than the $\mathrm{CO}_{2}$ from fossil fuel, the conclusion is drawn that the three explored development options should be combined. Consequently, the following recommendation is made: As a first step, increase the use of alternative fuel to reduce the emission of $\mathrm{CO}_{2}$ from fossil fuel and, in addition, reduce the use of fossil fuel and the environmental load associated with the production and transport of fossil fuel. Then, increase the use of recovered material in the cement mix to reduce $\mathrm{CO}_{2}$ emission and the use of thermal energy. Replace part of the limestone in raw meal with recovered material to further reduce $\mathrm{CO}_{2}$ emission and the use of thermal energy. The reduction in thermal energy use, in turn, will result in a reduction of $\mathrm{CO}_{2}$ emission from fuel combustion, and in resource use and emission to the air from the production of fossil fuel and transport of fossil and alternative fuels.

The use of recovered material should be increased to reduce $\mathrm{CO}_{2}$ emission and the use of thermal energy. This should be combined with an increase in the use of alternative fuel to reduce the use of fossil fuel, the emission of $\mathrm{CO}_{2}$ from fossil fuel and the environmental load associated with the production and transport of fossil fuel.

\section{Future research}

Detailed knowledge about the formation of, e.g., metal, dioxin and furan emissions and how these emissions depend on variations in raw material and fuel composition are needed. The life cycle process model should be complemented to include these.

The valuation of $\mathrm{CO}_{2}$ from different sources can be further explored. This includes both enlarging the model to include alternative waste treatment, as well as studies of the carbonisation rate of concrete.

The model was designed and built based on the commissioner's needs and requirements. And, the model is to be used to support decisions on product and process development options. Another interesting area for future research is to study to what extent the model supports decisions on product and process development options.

\section{Acknowledgements}

Cementa $\mathrm{AB}$ is gratefully acknowledged for financing the industrial doctoral project. The authors are also grateful to Bo-Erik Eriksson at Cementa $\mathrm{AB}$ for his valuable contribution to the project.

\section{References}

[1] Gäbel K, Forsberg P, Tillman A-M. The design and building of a life cycle-based process model for simulating environmental performance, product performance and cost in cement manufacturing. Journal of Cleaner Production 2004;12(1):77-93.

[2] According to Cement AB's Environmental Policy dated 2000-0815. Stockholm, Sweden; 2000.

[3] Cement- Part 1: Composition, specifications and conformity criteria for commencements. EN 197-1:2000. Brussels: European Committee for Standardization; 2000.

[4] QFDa 01 quality- and environmental handbook Cementa AB, version 3, dated 2001-01-08. Stockholm, Sweden; 2001.

[5] Gäbel K. Cement manufacturing - process- and material technology and related environmental aspects. Gothenburg, Sweden: Environmental Systems Analysis, Chalmers University of Technology, in press.

[6] Environmental management - life cycle assessment - goal and scope definition and inventory analysis. ISO 14041:1998. Geneva, Switzerland: International Organization for Standardization; 1998.

[7] Carlson R, Tillman A-M, Steen B, Löfgren G. LCI data modelling and a database design. International Journal of Life Cycle Assessment 1998;3(2):106-13.

[8] ETH - BUWAL 250 Data set, ETH 1994 ökoinventare für Energiesystem, Tab VI.11.3 (average) as cited in Cembureau LCI Format for cement.

[10] < http://www.deville.tep.chalmers.se $>$; 2001-02-22.

[11] <http://www.deville.tep.chalmers.se >; 2001-02-26.

\section{Further reading}

[9] Vold M, Rønning A. LCA of cement and concrete - main report, STØ (Stiftelsen Østfoldforskning). Norway: Fredrikstad; 1995. 